https://doi.org/10.18778/1509-877X.2019.02.03

\title{
PRZYCHÓD PRACOWNIKA Z TYTUŁU ZAPEWNIENIA PRZEZ PRACODAWCĘ NOCLEGÓW PODCZAS ODDELEGOWANIA DO PRACY POZA MIEJSCEM ZAMIESZKANIA
}

\begin{abstract}
Streszczenie. Nieodpłatne świadczenia pracownicze są coraz powszechniejszym zjawiskiem w ramach stosunku pracy. Stanowią bowiem niejednokrotnie istotny niepieniężny system motywacyjny. Mimo licznych orzeczeń Naczelnego Sądu Administracyjnego oraz wyroku Trybunału Konstytucyjnego zagadnienie opodatkowania podatkiem dochodowym takich świadczeń nadal budzi istotne wątpliwości. Definicji tego pojęcia w ustawie podatkowej nie ma, a wykładnia gramatyczna nie daje jednoznacznej odpowiedzi na pytanie, które ze świadczeń oferowanych pracownikom przez pracodawcę uznać za podlegające opodatkowaniu na podstawie art. 12 ust. 1 ustawy o podatku dochodowym od osób fizycznych.

Celem artykułu jest wykazanie, na przykładzie opodatkowania finansowanego przez pracodawcę zakwaterowania pracowników podczas oddelegowania ich do pracy poza miejscem zamieszkania, że w sytuacji, kiedy prawodawca nie tworzy (i nie definiuje) instytucji i pojęć swoistych dla prawa podatkowego - należy się posługiwać pojęciami i zasadami ukształtowanymi w innych gałęziach prawa. Prawo podatkowe jest bowiem elementem systemu prawa i jego rozwiązania należy harmonizować z unormowaniami innych gałęzi. System prawa powinien być spójny (wolny od niezgodności) i zupełny (wolny od luk). Przychodami ze stosunku pracy są wszystkie świadczenia, które pracownik otrzymuje od pracodawcy w związku z pozostawaniem w stosunku pracy. W tej sytuacji zasadne jest więc interpretowanie prawa podatkowego $\mathrm{w}$ powiązaniu ze stosownymi regulacjami $\mathrm{z}$ zakresu prawa pracy.
\end{abstract}

Słowa kluczowe: nieodpłatne świadczenie, przychód pracownika, koszty zakwaterowania, zasada spójności systemu prawa

* Naczelny Sąd Administracyjny, e-mail: mgrodecka@nsa.gov.pl 
1. W dzisiejszych czasach pracodawcy oferują pracownikom, poza tradycyjnym wynagrodzeniem, wiele nieprzewidzianych w umowie o pracę świadczeń, które motywują do podejmowania danej pracy (np. możliwość wykorzystywania samochodu służbowego czy telefonu do celów prywatnych, prywatna opieka medyczna, karnet na zajęcia fitness, refundacja kosztów noclegów czy dowozu do pracy itp.). Niejednokrotnie pracodawca ma trudności $\mathrm{z}$ oceną konsekwencji podatkowych takiej oferty pracowniczej: czy świadczenia te stanowią objęty podatkiem dochodowym (i obowiązkiem zapłaty składki ZUS) element wynagrodzenia za pracę, czy są wymaganymi przez odpowiednie przepisy świadczeniami ze strony pracodawcy, które służą stworzeniu odpowiednich warunków pracy (przepisy BHP) i które są zwolnione z tego podatku (art. 21 ust. 1 pkt 11 Ustawy z dnia 26 lipca 1991 r. o podatku dochodowym od osób fizycznych ${ }^{1}$ ). Ryzyko nieprawidłowego ustalenia wysokości zaliczki na podatek oraz ewentualnego zakresu opodatkowania spoczywa na pracodawcy ${ }^{2}$. Zgodnie bowiem z art. $30 \$ 1$ Ustawy z dnia 29 sierpnia 1997r. - Ordynacja podatkowa ${ }^{3}$ za podatek niepobrany oraz pobrany, ale niewpłacony, co do zasady odpowiedzialność ponosi pracodawca jako płatnik.

Pomimo wspomnianej powszechności występowania nieodpłatnych świadczeń na rzecz pracowników praktyka organów podatkowych oraz orzecznictwo sądów administracyjnych nie są jednolite ani co do równego traktowania wszystkich ich rodzajów, ani nawet w zakresie obejmującym konkretne świadczenie. Analizując praktykę organów podatkowych, można zauważyć, że - dbając o wpływy budżetowe - albo kwestionowana jest możliwość zaliczenia tego rodzaju wydatków do kosztów uzyskania przychodu pracodawcy, albo wymagane jest ich opodatkowanie jako nieodpłatnych świadczeń pracowniczych ${ }^{4}$.

Obecnie szczególnie istotne wątpliwości budzi kwestia opodatkowania finansowanego przez pracodawcę zakwaterowania pracowników podczas oddelegowania ${ }^{5}$ ich do pracy poza miejscem zamieszkania.

1 Tekst jedn. Dz.U. z 2020 r., poz. 1426 ze zm., dalej: u.p.d.o.f.

2 D. Strzelec, Świadczenia na rzecz pracowników. Aspekty podatkowe, Warszawa 2011.

3 Tekst jedn. Dz.U. z 2020 r., poz. 1325 ze zm., dalej: o.p.

4 D. Strzelec, Pozapłacowe świadczenia na rzecz pracowników - aspekty podatkowe, „Prawo i Podatki” 2010, nr 9, s. 6.

5 Tymczasowa zmiana miejsca wykonywania pracy, nie zaś podróż służbowa w rozumieniu art. $77^{5}$ Ustawy z dnia 26 czerwca 1974 r. - Kodeks pracy (tekst jedn. Dz.U. z 2020 r., poz. 1320), dalej „k.p.”. 
2. Zgodnie z art. 10 ust. 1 pkt 1 u.p.d.o.f. źródłem przychodu jest stosunek pracy. Stosownie zaś do art. 12 ust. 1 tego aktu za przychody ze stosunku służbowego, stosunku pracy, pracy nakładczej oraz spółdzielczego stosunku pracy uważa się wszelkiego rodzaju wypłaty pieniężne oraz wartość pieniężną świadczeń w naturze bądź ich ekwiwalenty, bez względu na źródło finansowania tych wypłat i świadczeń, a w szczególności: wynagrodzenia zasadnicze, wynagrodzenia za godziny nadliczbowe, różnego rodzaju dodatki, nagrody, ekwiwalenty za niewykorzystany urlop i wszelkie inne kwoty niezależnie od tego, czy ich wysokość została z góry ustalona, a ponadto świadczenia pieniężne ponoszone za pracownika, jak również wartość innych nieodpłatnych świadczeń lub świadczeń częściowo odpłatnych. Wyliczenie zawarte w powyższym katalogu ma charakter otwarty, a to ze względu na użycie sformułowań „wszelkie wypłaty” oraz „wartość innych [...] świadczeń". Oznacza to, że dla kwalifikacji danego przychodu jako przychodu pochodzącego ze stosunku pracy (i stosunków pokrewnych) decydujące znaczenie ma nie nazwa świadczenia czy też tytuł wypłaty, ale przede wszystkim to, $\mathrm{z}$ jakiego stosunku jest ono otrzymywane, od kogo pochodzi i na czyją rzecz jest dokonywane. Świadczeniodawcą (dokonującym) wypłaty jest pracodawca, natomiast beneficjentem jest pracownik (ewentualnie były pracownik) ${ }^{6}$.

Wartość pieniężną innych nieodpłatnych świadczeń lub świadczeń częściowo odpłatnych ustala się według zasad określonych w art. 11 ust. 2-2b u.p.d.o.f.

3. Wskazane powyżej przepisy wprawdzie regulują sposób ustalania wartości pieniężnych nieodpłatnych świadczeń, ale nie zawierają ich definicji, a zatem wskazują, jak wycenić ich wartość, ale nie mówią, co tym nieodpłatnym świadczeniem jest. Zakładając racjonalność prawodawcy, w takiej sytuacji należałoby uznać, że definicja jest zbędna, ponieważ dla ustalenia zakresu znaczeniowego danego pojęcia wystarczą te przepisy, które są ${ }^{7}$.

Co do zasady w doktrynie w przypadku braku ustawowej definicji wskazywane są dwa rozwiązania: sięgnięcie do pojęć języka potocznego lub do terminologii prawa cywilnego ${ }^{8}$. W sytuacji bowiem, gdy przepis

${ }^{6}$ A. Bartosiewicz, R. Kubacki, PIT. Komentarz, Warszawa 2015.

7 J. Grabarczyk, Opodatkowanie przychodów z nieodpłatnych świadczeń, Warszawa 2009, s. 89.

8 R. Mastalski, Stosowanie prawa podatkowego, Warszawa 2008, s. 23. 
ustawy nie definiuje danego pojęcia, w procesie wykładni przepisów prawa podatkowego podstawową rolę odgrywa wykładnia gramatyczna, a więc znaczenie danego zwrotu/terminu w języku powszechnym ${ }^{9}$. W tym zakresie można się odwołać do trzech źródeł: opinii biegłych językoznawców, intuicji językowej i słowników językowych ${ }^{10}$.

Zgodnie ze słownikowym znaczeniem przez „świadczenie”"1 należy rozumieć „obowiązek wykonania lub przekazania czegoś na czyjąś rzecz”, a „nieodpłatne” 12 oznacza „niewymagające opłaty”. Warunkiem otrzymania nieodpłatnego świadczenia (w tym przypadku pracowniczego) jest więc wystąpienie po stronie pracodawcy przekazania świadczenia. „Ma to istotne znaczenie z punktu widzenia konstruowanej definicji nieodpłatnych świadczeń. Zaniechanie działania nie może być bowiem poczytywane jako przekazanie świadczenia. Tym samym z nieodpłatnym świadczeniem będziemy mieć do czynienia w sytuacji działania celem przekazania takiego świadczenia dla konkretnej osoby"13.

Tak sformułowana definicja nie daje jednoznacznej odpowiedzi na pytanie, czy opłacenie przez pracodawcę kosztów noclegu pracowników podczas oddelegowania do pracy poza miejsce zamieszkania jest nieodpłatnym świadczeniem podlegającym opodatkowaniu podatkiem dochodowym od osób fizycznych. W tym przypadku przepisy prawa cywilnego również nie pomagają. Naczelny Sąd Administracyjny (NSA) - podejmując próby ustalenia znaczenia terminu „nieodpłatne świadczenie” w podatku dochodowym zarówno od osób prawnych ${ }^{14}$, jak i fizycznych ${ }^{15}$ - wielokrotnie podkreślał, że w prawie podatkowym pojęcie to ma szerszy zakres niż w prawie cywilnym. Obejmuje bowiem wszystkie zjawiska gospodarcze i zdarzenia prawne, których następstwem jest uzyskanie korzyści kosztem innego

9 B. Brzeziński, Podstawy wykładni prawa podatkowego, Gdańsk 2008, s. 44.

10 A. Bielska-Brodziak, Interpretacja tekstu prawnego na podstawie orzecznictwa podatkowego, Warszawa 2009.

11 https://sjp.pwn.pl/szukaj/\%C5\%9Bwiadczenie.html

12 https://sjp.pwn.pl/szukaj/nieodp\%C5\%82atny.html

13 A. Mariański, A. Nowak-Piechota, Konstytucyjność opodatkowania pozapłacowych świadczeń pracowniczych, „Przegląd Podatkowy” 2014, nr 11, s. 43-48.

${ }^{14}$ Uchwała NSA z dnia 18 listopada 2002 r., sygn. FPS 9/02, ONSA 2003, nr 2, poz. 47; uchwała NSA z dnia 16 października 2006 r., sygn. II FPS 1/06, ONSAiWSA 2006, nr 12, poz. 153.

15 Uchwała NSA z dnia 24 maja 2010 r., sygn. II FPS 1/10, ONSAiWSA 2010, nr 4, poz. 58; uchwała NSA z dnia 24 października 2011 r., sygn. II FPS 7/10, ONSAiWSA 2012, nr 1, poz. 1 . 
podmiotu, lub te wszystkie zdarzenia prawne i zdarzenia gospodarcze, których skutkiem jest nieodpłatne, tj. niezwiązane $z$ kosztami lub inną formą ekwiwalentu, przysporzenie majątku tej osobie, mające konkretny wymiar finansowy. Podobnie Trybunał Konstytucyjny (TK) w wyroku z dnia 8 lipca 2014 r. ${ }^{16}$ zaakcentował, że tworząc pojęcie nieodpłatnego świadczenia w podatkach dochodowych, niezasadne jest odwoływanie się do pojęć prawa cywilnego. Wskazano bowiem, że ograniczenie omawianego terminu do darowizny w rozumieniu prawa cywilnego (działanie donandi causa) nie ma uzasadnienia na gruncie ustawy o podatku dochodowym od osób fizycznych. Zauważono, że w ramach stosunków pracowniczych pracodawca nie działa wobec pracownika z zamiarem szczodrobliwości (obdarowania).

Jak podkreślił Trybunał, definiując pojęcie „nieodpłatnego świadczenia” w rozumieniu art. 12 ust. 1 u.p.d.o.f., to nie zamiar obdarowania stanowi kryterium odróżnienia świadczeń pracodawcy, o których wartość należy podnieść podlegający opodatkowaniu dochód pracownika, od tych, które jego dochodu nie zwiększają. Kryterium tym musi być obiektywna ocena, w czyim interesie leżało spełnienie danego świadczenia. Świadczenie nie podlega opodatkowaniu podatkiem dochodowym, jeżeli jego spełnienie leży przede wszystkim w interesie pracodawcy, który - bez poczynienia wymaganych przez przepisy (przede wszystkim BHP) wydatków - nie mógłby zorganizować produkcji, czy szerzej - własnej działalności gospodarczej. Korzyść ze świadczeń spełnianych na rzecz pracownika, zgodnie z pkt 3.3.2 wyroku TK, „nie jest przez niego wynoszona na zewnątrz stosunku pracy". Zdaniem Trybunału świadczenie leży w interesie pracownika wtedy, gdy: stanowi realne przysporzenie majątkowe (korzyść), którego efekt jest uchwytny w jego majątku, którym może swobodnie zarządzać i rozporządzać, przeznaczając je na zaspokojenie własnych potrzeb, które pozwala mu na uniknięcie wydatków. Zgoda pracownika na skorzystanie ze świadczenia wyraża zaś jego ocenę, że świadczenie - z punktu widzenia jego sytuacji zawodowej, życiowej, rodzinnej - jest celowe i przydatne, leży w jego interesie.

W konsekwencji Trybunał Konstytucyjny w powołanym wyroku wskazał cechy, jakie musi spełniać świadczenie, aby uznać je za pozapłacowe nieodpłatne świadczenie pracownicze podlegające opodatkowaniu na gruncie ustawy o podatku dochodowym od osób fizycznych:

16 Sygn. K 7/13, OTK-A 2014, nr 7, poz. 69. 
1) musi być spełnione za zgodą pracownika (skorzystał $\mathrm{z}$ niego w pełni dobrowolnie),

2) zostało spełnione $\mathrm{w}$ jego interesie (a nie $\mathrm{w}$ interesie pracodawcy) i przyniosło mu korzyść w postaci powiększenia aktywów lub uniknięcia wydatku, który musiałby ponieść,

3) korzyść ta jest wymierna i przypisana indywidualnemu pracownikowi (nie jest dostępna w sposób ogólny dla wszystkich podmiotów).

W ocenie TK powyższy szablon pozwala na jednoznaczne ustalenie przy każdym świadczeniu oferowanym pracownikowi przez pracodawcę, czy stanowi ono opodatkowane nieodpłatne świadczenie $\mathrm{w}$ rozumieniu art. 12 ust. 1 u.p.d.o.f. Wyrok ten - uważany przez niektórych ${ }^{17}$ za kamień milowy w próbach zharmonizowania rozbieżności stanowisk co do opodatkowania nieodpłatnych świadczeń pracowniczych - pojawiające się wątpliwości częściowo rozwiał, jednakże - jak pokazuje analiza najnowszych orzeczeń NSA w przedmiocie poniesienia przez pracodawcę kosztów noclegów podczas oddelegowania pracowników do pracy poza siedzibę pracodawcy, a jednocześnie poza miejsce zamieszkania pracowników - zagadnienie to nadal budzi wiele kontrowersji.

W takich przypadkach, spośród wskazanych przez Trybunał Konstytucyjny cech świadczenia, które ma spełniać nieodpłatne świadczenie w rozumieniu art. 12 ust. 1 u.p.d.o.f., w orzecznictwie NSA nie ma wątpliwości co do: opisanej w punkcie pierwszym (musi być spełnione za zgodą pracownika) oraz w punkcie trzecim (korzyść ta jest wymierna i przypisana indywidualnemu pracownikowi). Jak wskazano w wyroku NSA z dnia 16 stycznia 2020 r. $^{18}$, zgoda pracownika nie musi być wyrażona wprost. W tej sprawie, w opisie stanu faktycznego/zdarzenia przyszłego we wniosku o wydanie indywidualnej interpretacji ${ }^{19}$ nie zastrzeżono

17 P. Brejdak, Glosa do wyroku Trybunału Konstytucyjnego z dnia 8 lipca 2014 r., sygn. akt K 7/13, „Roczniki Nauk Prawnych” 2016, t. 26, nr 1, s. 161-171.

18 Sygn. II FSK 524/18 (wszystkie powołane w tekście orzeczenia NSA dostępne są w Centralnej Bazie Orzeczeń Sądów Administracyjnych, http://orzeczenia.nsa.gov.pl/).

19 Analiza orzecznictwa NSA dotyczącego podatkowych aspektów nieodpłatnych świadczeń jest wynikiem kontroli interpretacji indywidualnych przepisów prawa podatkowego. W ramach tej kontroli przedmiotem sporu zasadniczo nie mogą być okoliczności związane ze stanem faktycznym. Zarówno bowiem organ podatkowy wydający interpretację, jak i sądy administracyjne wypowiadają się w ramach stanu faktycznego przedstawionego przez wnioskodawcę i niepoddawanego weryfikacji. Orzecznictwo NSA w zakresie uznania za przychód sfinansowanych przez pracodawcę kosztów noclegów pracownika oddelegowanego do pracy poza siedzibę pracodawcy i poza miejscowość jego 
braku zgody na korzystanie z tego świadczenia przez pracownika. Wprawdzie spółka podniosła, że warunek dobrowolności nie został spełniony, lecz jednocześnie wskazała, że zmiana miejsca pracy pracownika na okres oddelegowania jest uzgodniona $\mathrm{z}$ pracownikiem na mocy porozumienia stron. Nie można zatem twierdzić, że pracownik wbrew swej woli mógł zostać skierowany do pracy poza miejscem stałego zamieszkania i w konsekwencji przyjąć udostępnione do zakwaterowania miejsce. Zdaniem Sądu nie budzi również wątpliwości indywidualizacja osób, które uzyskują tego rodzaju przychody. Pracodawcy wiadome jest, który pracownik i ile dni świadczy pracę poza stałym miejscem zamieszkania oraz z jakiego lokalu wynajętego przez spółkę korzysta.

Rozbieżności co do uznania, czy analizowane świadczenie należy opodatkować podatkiem dochodowym od osób fizycznych pojawiają się zaś w związku ze wskazaną przesłanką korzyści dla pracownika lub pracodawcy. Przedstawione powyżej próby zdefiniowania pojęcia „nieodpłatne świadczenie" przez orzecznictwo sądów administracyjnych i Trybunału Konstytucyjnego nie dają jednoznacznej odpowiedzi na pytanie, które $\mathrm{z}$ różnego rodzaju świadczeń oferowanych w dzisiejszych czasach przez pracodawców swoim pracownikom stanowią przychód w podatku dochodowym od osób fizycznych. Jest to problem zarówno dla pracowników jako podatników podatku dochodowego od osób fizycznych, jak i ich pracodawców, wadliwe zakwalifikowanie danego świadczenia jako niestanowiącego nieodpłatnego świadczenia rodzi bowiem odpowiedzialność pracodawcy jako płatnika podatku dochodowego od osób fizycznych (art. 26a w ZW. $z$ art. $30 \$ 1$ o.p.).

4. Prawo podatkowe jest elementem systemu prawa i jego rozwiązania powinny być zharmonizowane $z$ unormowaniami innych gałęzi. System prawa powinien być spójny (to jest wolny od niezgodności) i zupełny (wolny od luk) ${ }^{20}$. Oznacza to, że wszędzie tam, gdzie prawodawca nie tworzy (i nie definiuje) instytucji i pojęć swoistych dla tego prawa, należy się posługiwać pojęciami i zasadami ukształtowanymi w innych gałęziach prawa. Analizując zależności pomiędzy prawem podatkowym a prawem

zamieszkania szczególnie dobitnie świadczy o tym, jak bardzo rozstrzygnięcie sprawy sądowej w przedmiocie uznania danego świadczenia za „nieodpłatne świadczenie” w rozumieniu art. 12 ust. 1 u.p.d.o.f. zależy od stanu faktycznego sprawy.

20 R. Mastalski, Autonomia prawa podatkowego a spójność i zupełność systemu prawa, „Przegląd Podatkowy” 2003, nr 10. 
prywatnym, należy bowiem uznać prawo podatkowe za „wtórne” w tym sensie, że zgodnie z typową normą podatkowoprawną przedmiotem opodatkowania jest sytuacja faktyczna lub prawna, $z$ wystąpieniem której wiąże się obowiązek zapłaty podatku ${ }^{21}$ ( $\mathrm{z}$ reguły jest to zdarzenie uregulowane w przepisach prawa prywatnego, np. zawarcie umowy cywilnoprawnej lub jej skutek w postaci wypłaty wynagrodzenia, wypłata pracownikowi wynagrodzenia z tytułu umowy o pracę). Z tego punktu widzenia można stwierdzić, że współcześnie istnienie regulacji prawa podatkowego jest determinowane faktycznie istnieniem regulacji prawa prywatnego, ponieważ to te ostatnie pozwalają ustalić podatkowy stan faktyczny ${ }^{22}$. Ze względu na to, że dopiero poprawna wykładnia przepisów prawa prywatnego pozwala na ustalenie stanu faktycznego, kwalifikowanego na gruncie przepisów podatkowych, prawo podatkowe jest w doktrynie określane również mianem „prawa podwójnej wykładni”23.

Niewątpliwie więc korzystanie przez ustawodawcę oraz przez podmioty stosujące prawo podatkowe $\mathrm{z}$ rozwiązań innych gałęzi prawa materializuje zasadę spójności i jedności prawa, czy też całego systemu prawnego. Prawodawca nie powinien normować w danej gałęzi (w tym przypadku w prawie podatkowym) zagadnień, które już są w systemie unormowane i mogą stanowić właściwy instrument realizacji założonych przez niego celów ${ }^{24}$. Należy przyjąć, że użyte w przepisach prawa podatkowego pojęcia, mające ustalone znaczenie $\mathrm{w}$ innych dziedzinach prawa, mają to samo znaczenie w prawie podatkowym, chyba że przepis prawa podatkowego inaczej stanowi (zasada respektowania pojęć przejętych $\mathrm{z}$ innych dziedzin prawa $)^{25}$.

${ }^{21}$ K. Ostrowski, Prawo finansowe. Zarys ogólny, Warszawa 1970, s. 144.

${ }_{22}$ M. Bosak, P. Majka, Wpływ regulacji podatkowoprawnych na stosunek pracy $w$ świetle funkcji ochronnej prawa pracy, referat wygłoszony podczas XIX Zjazdu Katedr i Zakładów Prawa Pracy i Ubezpieczeń Społecznych zorganizowanego przez Katedrę Prawa Pracy i Prawa Socjalnego na Wydziale Prawa i Administracji Uniwersytetu im. Adama Mickiewicza w Poznaniu, 15-17 maja 2013 r.

${ }^{23}$ B. Brzeziński, Wstęp do nauki prawa podatkowego, Toruń 2003, s. 151; szerzej na temat związków prawa podatkowego z prawem cywilnym zob. B. Brzeziński, Prawo podatkowe a prawo cywilne, [w:] Prawo podatkowe. Teoria. Instytucje. Funkcjonowanie, red. B. Brzeziński, Toruń 2009, s. 391 i n.; A. Gomułowicz, J. Małecki, Podatki i prawo podatkowe, Warszawa 2002, s. 191-201; P. Karwat, Obejście prawa podatkowego. Natura zjawiska i sposoby przeciwdziałania mu, Warszawa 2002, s. 42-46.

24 R. Mastalski, Autonomia prawa podatkowego...

25 B. Brzeziński, W. Nykiel, Zasady ogólne prawa podatkowego, „Przegląd Podatkowy" 2002, nr 3. 
5. Przychodami ze stosunku pracy są wszystkie świadczenia, które pracownik otrzymuje od pracodawcy w związku z pozostawaniem w stosunku pracy. W takiej sytuacji zasadne jest interpretowanie prawa podatkowego (w tym przypadku - nieodpłatnych świadczeń pracowniczych) w powiązaniu ze stosownymi regulacjami z zakresu prawa pracy. Z tych względów, nie znajdując w wyroku Trybunału Konstytucyjnego jednoznacznej odpowiedzi na pytanie, czy wydatki pracodawcy na noclegi dla pracowników stanowią nieodpłatne świadczenie w rozumieniu art. 12 ust. 1 u.p.d.o.f., do przepisów Kodeksu pracy (w szczególności art. 94) odwołał się wielokrotnie Naczelny Sąd Administracyjny ${ }^{26}$.

Przepis art. 94 k.p. stanowi m.in., że pracodawca jest obowiązany w szczególności: organizować pracę w sposób zapewniający pełne wykorzystanie czasu pracy, jak również osiąganie przez pracowników, przy wykorzystaniu ich uzdolnień i kwalifikacji, wysokiej wydajności i należytej jakości pracy (pkt 2), organizować pracę w sposób zapewniający zmniejszenie uciążliwości pracy, zwłaszcza pracy monotonnej i pracy w ustalonym z góry tempie (pkt 2a). Jak podkreślił NSA we wskazanych orzeczeniach (odnotowując w tym zakresie także stosowne orzecznictwo Sądu Najwyższego), przepisy prawa, w tym przepisy dotyczące bezpieczeństwa i higieny pracy, nie obligują pracodawcy do zapewnienia pracownikowi miejsca zamieszkania, w którym będzie zaspokajał swoje potrzeby bytowe. Jest to sfera prywatna pracownika, realizowana poza godzinami pracy i poza dyspozycją pracodawcy. Z samego faktu zamieszkiwania poza stałym miejscem pobytu (w miejscu wykonywania pracy) nie wynika, że pracownik pozostaje w dyspozycji pracodawcy i że używa lokalu, w którym został zakwaterowany, w celach służbowych ${ }^{27}$. Udostępniona kwatera (lokal) nie jest „narzędziem” pracy, którego koszty obciążałyby pracodawcę, ale służy realizacji pozapracowniczych potrzeb życiowych (socjalnych). O ile zatem pracodawca jest organizatorem pracy i ma zapewnić warunki techniczno-organizacyjne wykonywania pracy (przygotować stanowisko pracy wraz z urządzeniami, narzędziami i materiałami), o tyle obowiązek ten nie rozciąga się na zapewnienie pracownikowi noclegu. Oczywiście w przypadku

${ }^{26}$ Wyroki NSA: z dnia 29 listopada 2018 r., sygn. II FSK 799/18; z dnia 23 lipca 2019 r., sygn. II FSK 2721/17; z dnia 19 września 2019 r., sygn. II FSK 3365/17; z dnia 24 października 2019 r., sygn. II FSK 3658/17; z dnia 26 listopada 2019 r., sygn. II FSK 3953/17.

27 W przypadku podróży służbowej (art. $77^{5} \$ 1$ k.p.) pracownik pozostaje w dyspozycji pracodawcy, a związany z nią nocleg poza miejscem zamieszkania nie jest wpisany w umówiony charakter pracy. 
znacznych odległości między miejscem zamieszkania a miejscem wykonywania obowiązków zakwaterowanie pracownika jest niezbędne, aby zobowiązanie pracownicze mogło być realizowane, ale nie jest to warunek prawny, lecz faktyczny, na który pracownik, nawiązując stosunek pracy na takich warunkach (z miejscem pracy określonym jako pewien obszar geograficzny), godzi się dobrowolnie. Jeżeliby oceniać tę kwestię (z wyłączeniem podróży służbowych) z perspektywy warunku niezbędnego do zgodnego z prawem wykonywania pracy (obciążającego pracodawcę), to jedynie w aspekcie prawa pracownika do takiego wynagrodzenia, aby odpowiadało rodzajowi wykonywanej pracy (art. $78 \$ 1$ k.p.) i było godziwe (art. 13 k.p.). W przypadku pracy wymuszającej czasowe zamieszkanie pracownika poza jego centrum życiowym - wynagrodzenie powinno być więc tak ustalone, aby uwzględniało taki życiowo uciążliwy charakter pracy.

Jak zaś wskazano w uzasadnieniu wyroku NSA z dnia 26 listopada 2019 r. $^{28}$, „zasadą powinno być, że pracownik za swoją pracę otrzymuje wynagrodzenie (świadczenie pieniężne), a nieodpłatne świadczenia stanowią wyjątek od tej zasady, uzasadniony między innymi względami praktycznymi, w tym ekonomicznymi, np. ze względu na ulgi przy grupowym ubezpieczeniu, zakwaterowaniu czy przy zbiorczych pakietach medycznych. Ta zasada odpowiedniej płacy ma także uzasadnienie $z$ ekonomicznego punktu widzenia. Zbyt niskie wynagrodzenie za pracę, nieuwzględniające kosztów pracownika ponoszonych w związku z wykonywaniem zwykłych - bo wynikających z umowy o pracę - obowiązków, może spowodować nieatrakcyjność oferty pracodawcy na rynku pracy, gdyż podjęcie takiej pracy może być oceniane jako «nieopłacalne». Jeśli pracodawca uwzględnia (musi uwzględniać) ten aspekt w wysokości wynagrodzenia, ale ze względów organizacyjnych, praktycznych decyduje się na nieodpłatne świadczenie $\mathrm{w}$ postaci udostępnienia pracownikom nieodpłatnych noclegów (mających wymierną wartość ekonomiczną), to nadal jest to zapłata za pracę. Gdyby zatem przyjąć, że ponoszenie przez pracodawcę wydatków w celu zapewnienia noclegów pracownikowi mobilnemu jest świadczeniem poniesionym $w$ interesie pracodawcy, ponieważ to jemu przynosi konkretną i wymierną korzyść w postaci prawidłowo i efektywnie wykonanej przez pracownika pracy, to również taki charakter miałoby wynagrodzenie za pracę np. w formie dodatku «za mobilność», a nie budzi wątpliwości, że wynagrodzenie jest przychodem pracownika. Oceniając zatem

28 Sygn. II FSK 3953/17. 
obiektywnie, dobrowolne przyjęcie od pracodawcy nieodpłatnego zakwaterowania leży w interesie pracownika mobilnego, gdyż uzyskuje on w ten sposób wymierną korzyść (przysporzenie majątkowe) w postaci uniknięcia kosztów, które musiałby ponieść, skoro zdecydował się na wynikające $\mathrm{z}$ umowy o pracę «mobilne» miejsce pracy" 29 .

Wśród prezentowanych orzeczeń są takie, które dotyczyły pracowników oddelegowanych do pracy za granicę. Kwestie delegowania pracowników przez pracodawcę do innego państwa UE uregulowane są zaś dyrektywą 96/71/WE Parlamentu Europejskiego i Rady z dnia 16 grudnia 1996 r. dotyczącą delegowania pracowników w ramach świadczenia usług ${ }^{30}$. Dyrektywa ta, gwarantująca odpowiednią ochronę praw pracowników delegowanych, a jednocześnie zapewniająca przedsiębiorcom swobodne świadczenie usług z wykorzystaniem instytucji delegowania, została implementowana do polskiego porządku prawnego Ustawą z dnia 10 czerwca 2016 r. o delegowaniu pracowników w ramach świadczenia usług ${ }^{31}$. Dyrektywa 96/71 stanowi podstawowy zbiór warunków zatrudnienia, które mają być spełnione przez pracodawcę-usługodawcę w celu zapewnienia minimalnego poziomu ochrony pracowników delegowanych. Pracodawca, delegując pracownika za granicę, powinien zagwarantować mu przynajmniej minimalne warunki zatrudnienia obowiązujące $\mathrm{w}$ państwie przyjmującym $^{32}$. Regulacje te dotyczą zasad „delegowania pracowników w ramach świadczenia usług”, nie regulują natomiast zasad opodatkowania podatkami bezpośrednimi ${ }^{33}$, co na pierwszy rzut oka oznacza, że dyrektywa ta nie ma zastosowania $\mathrm{w}$ przypadku ustalania, czy dane świadczenie jest nieodpłatnym świadczeniem w rozumieniu art. 12 ust. 1 u.p.d.o.f. Niemniej jednak można wyobrazić sobie sytuację, w której strona podniesie, że zapewnienie noclegu pracownikom oddelegowanym do pracy za granicę stanowi obowiązek pracodawcy wynikający z dyrektywy 96/71, pracownicy zatrudnieni na takim samym stanowisku w państwie członkowskim UE mają bowiem tego typu świadczenie prawnie zagwarantowane. To będzie

${ }^{29}$ Odmiennie wyroki NSA: z dnia 19 września 2014 r., sygn. II FSK 2280/12; z dnia 9 sierpnia 2016 r., sygn. II FSK 1970/14.

${ }^{30}$ Dz.Urz. WE L 18 z dnia 21 stycznia 1997 r., s. 1; Dz.Urz. UE Polskie wydanie specjalne, rozdz. 5, t. 2, s. 431, dalej: dyrektywa 96/71.

31 Dz.U. z 2016 r., poz. 868.

32 Szerzej M. Skibińska, A. Sokołowska, Delegowanie pracowników za granice, Warszawa 2016.

33 Por. wyrok NSA z dnia 23 lipca 2020 r., sygn. II FSK 1094/18. 
zaś oznaczało konieczność sięgnięcia w sposób pośredni do omawianych regulacji przy ocenie przesłanki uznania noclegów dla pracowników za nieodpłatne świadczenie (art. 12 ust. 1 u.p.d.o.f.).

Przywołane powyżej przykłady dotyczyły spraw, w których do pracy poza miejscowość zamieszkania pracownika oddelegowano osoby zatrudniane do robót ogólnobudowlanych. W ocenie NSA inaczej natomiast należy interpretować wydatki na noclegi dla przedstawicieli handlowych. W zakresie opodatkowania noclegów przedstawicieli handlowych uznano, że nie jest to przychód pracownika w rozumieniu wskazanego przepisu ${ }^{34}$. $\mathrm{W}$ tych sprawach, we wnioskach o wydanie indywidualnej interpretacji podatkowej pracodawcy wskazywali, że w umowach o pracę jako miejsce świadczenia pracy jest (będzie) wskazany określony region, województwo lub też obszar całej Polski. Osoby te będą w sposób stały świadczyły pracę poza siedzibą przedsiębiorcy (kontakty handlowe z klientami). W przypadku pracowników, dla których siedziba pracodawcy nie będzie miejscem świadczenia pracy, wyjazdów związanych z wykonywaniem pracy do różnych miejsc na terenie kraju nie można - w świetle przepisów prawa pracy - traktować jako podróży służbowej (delegacji). Podobnie jak w przypadku typowych delegacji, zdarzają się takie sytuacje, że osoby muszą nocować w miejscu wykonywania swoich czynności służbowych ze względu na brak możliwości powrotu w tym samym dniu do miejsca zamieszkania. Przedsiębiorca, jako pracodawca tych osób, będzie pokrywał koszty związane $\mathrm{z}$ tymi noclegami.

Zdaniem NSA w takich przypadkach ponoszenie przez pracodawcę wydatków w celu zapewnienia noclegów pracownikowi jest świadczeniem poniesionym $\mathrm{w}$ interesie pracodawcy, ponieważ to jemu przynosi konkretną i wymierną korzyść w postaci prawidłowo i efektywnie wykonanej przez pracownika pracy. Przepisy prawa pracy nie nakładają zaś na pracownika obowiązku ponoszenia za pracodawcę wydatków związanych ze świadczeniem pracy, a wszystkie wynikające stąd koszty winien pokrywać zatrudniający. W tych orzeczeniach, podobnie jak w przypadku przychodów pracowników budowlanych, także nawiązano do treści art. 94 k.p. W ocenie NSA „obowiązek zapewnienia prawidłowej organizacji pracy nie może być utożsamiany tylko z zapewnieniem biurka, materiałów biurowych czy

34 Por. wyroki NSA: z dnia 2 października 2014 r., sygn. II FSK 2387/12; z dnia 23 lutego 2017 r., sygn. II FSK 234/15; z dnia 19 września 2017 r., sygn. II FSK 2039/15; z dnia 15 kwietnia 2016 r., sygn. II FSK 635/14. 
pokryciem kosztów eksploatacji samochodu służbowego czy kosztów zużytej energii elektrycznej. Ten obowiązek należy i trzeba odnosić i analizować w kontekście konkretnych obowiązków pracowniczych i wynikających z tych obowiązków oczekiwań pracodawcy. Skoro więc prawidłowe i efektywne wykonywanie obowiązków pracowniczych wymaga od pracownika nocowania w hotelu, aby w określonym czasie wynikającym z kontaktów handlowych pracodawcy i kontrahenta dotrzeć do kontrahenta, to zapewnienie tej możliwości przez pracodawcę nie jest korzyścią pracownika, ale właśnie wypełnieniem przez pracodawcę ustawowego obowiązku prawidłowego organizowania pracy tak, aby była ona wydajna i należytej jakości. Zapewnienie możliwości nocnego wypoczynku odpowiada także obowiązkowi pracodawcy organizowania pracy w sposób zmniejszający uciążliwość pracy"35. Przepis art. 94 k.p. tylko przykładowo wymienia w aspekcie zmniejszenia uciążliwości pracy pracę monotonną i pracę $\mathrm{w}$ ustalonym z góry tempie. Dodatkowo, jak wskazano w wyroku NSA z dnia 23 lutego $2017 \mathrm{r}^{36}{ }^{36}$, poniesione przez pracowników spółki wydatki mają bezpośredni związek z wykonywaniem obowiązków służbowych wynikających z umowy o pracę. Na pewno wydatki te nie mają związku z potrzebami osobistymi pracowników, a wyłącznie $\mathrm{z}$ celami służbowymi. W trakcie świadczenia pracy, zatrudnieni pracownicy wydatkują środki finansowe w związku z wykonywaniem określonych zadań na rzecz pracodawcy. Do realizacji tych zadań pracownik musi korzystać z noclegu poza miejscem zamieszkania. Wydatki z tym związane są zwracane pracownikowi po przeprowadzonej kontroli dokumentów potwierdzających ich poniesienie. Tym samym, spółka dokonuje pełnej oceny zasadności korzystania przez pracownika z noclegu poza miejscem zamieszkania. Rozstrzyga i uznaje, czy poniesione wydatki były w interesie pracodawcy, czy też nie. Dopiero pozytywna odpowiedź na to pytanie powoduje zwrot poniesionych wydatków pracownikowi. W takiej sytuacji nie znajduje uzasadnienia stanowisko, że otrzymywany przez pracownika zwrot poniesionych wydatków na nocleg stanowi otrzymane przez niego świadczenie, które jest spełniane w jego interesie, a nie pracodawcy. Zapłata przez pracodawcę kosztu noclegu pracownika wykonującego swoje obowiązki w miejscu określonym w umowie o pracę (poza siedzibą firmy oraz miejscem zamieszkania pracownika) stanowi racjonalny wydatek firmy związany z realizacją określonych celów

\footnotetext{
35 Wyrok NSA z dnia 2 października 2014 r., sygn. II FSK 2387/12.

${ }^{36}$ Sygn. II FSK 234/15.
} 
gospodarczych. Wydatek ten jest ponoszony w interesie pracodawcy i stanowi koszt działalności gospodarczej poniesiony w celu osiągnięcia przychodów firmy".

W podobny sposób NSA ocenił zapewnienie funkcjonariuszowi Służby Więziennej tymczasowej kwatery poza miejscem zamieszkania. W tym przypadku również uznano, że korzystanie z kwatery czasowej przez funkcjonariusza przeniesionego z urzędu do pełnienia służby w innej miejscowości jest świadczeniem spełnionym w interesie pracodawcy. Zapewnienie funkcjonariuszowi miejsca zakwaterowania w miejscu pełnienia służby jest bowiem obowiązkiem pracodawcy, który zobligowany jest do zapewnienia pełnego wykorzystania efektywnego czasu pracy, a tym samym to pracodawca odnosi korzyść z tego tytułu, mogąc prawidłowo realizować zadania wynikające z przepisów ustawy o Służbie Więziennej. Zdaniem Sądu „pracę łączącą się z rozłąką z rodziną, czy też z innymi bliskimi uznać należy za uciążliwą i łagodzenie tych niedogodności jest obowiązkiem pracodawcy, a nie przywilejem czy jakąkolwiek korzyścią pracownika" ${ }^{37}$.

Także w przypadku pracowników projektowych zatrudnionych w spółce świadczącej usługi związane z poszukiwaniem i eksploatacją złóż gazu, wskazując na analogiczną argumentację, NSA uznał, że zapewnienie im noclegów w miejscu wykonywania odwiertów i projektów nie stanowi przychodu określanego jako wartość innych nieodpłatnych świadczeń w rozumieniu art. 12 ust. $1 \mathrm{w}$ zw. $\mathrm{z}$ art. 11 ust. 1 u.p.d.o.f. ${ }^{38}$

6. O konieczności powiązania świadczeń pracowniczych na gruncie prawa podatkowego z regulacjami prawa pracy mogą również świadczyć regulacje dotyczące ustalania składek ZUS od tych świadczeń. Zgodnie bowiem z art. 18 ust. 1 Ustawy z dnia 13 października 1998 r. o systemie ubezpieczeń społecznych $^{39}$ zasadą jest, że podstawę wymiaru składek na ubezpieczenia emerytalne i rentowe ubezpieczonych wymienionych m.in. w art. 6 ust. 1 pkt 1 ustawy systemowej, czyli pracowników (z wyjątkiem prokuratorów), stanowi przychód, o którym mowa w art. 4 pkt 9 tego aktu. Stosownie zaś do art. 4 pkt 9 ustawy systemowej przychodem w rozumieniu tego aktu jest przychód w rozumieniu przepisów o podatku dochodowym od osób fizycznych, m.in. $z$ tytułu zatrudnienia w ramach stosunku pracy. Jak uznał Sąd

37 Wyrok NSA z dnia 5 lutego 2020 r., sygn. II FSK 742/18.

38 Wyrok NSA z dnia 17 maja 2017 r., sygn. II FSK 1132/15.

39 Tekst jedn. Dz.U. z 2020 r., poz. 266 ze zm., dalej: ustawa systemowa. 
Najwyższy (SN) w uchwale z dnia 10 grudnia $2015 \mathrm{r}^{40}$, „pojęcie przychodu określone w art. 4 ust. 9 ustawy systemowej obejmuje wartość świadczeń ponoszonych przez pracodawcę $\mathrm{z}$ tytułu zakwaterowania pracowników i tym samym stanowi podstawę wymiaru składek na ubezpieczenia społeczne w rozumieniu art. 18 ust. 1 tej ustawy". W ocenie SN przyjęcie od pracodawcy nieodpłatnego zakwaterowania leży w interesie pracownika mobilnego, gdyż uzyskuje on w ten sposób wymierną korzyść w postaci uniknięcia kosztów (przysporzenie majątkowe), które musiałby ponieść, skoro zdecydował się na wynikające z umowy o pracę „mobilne” miejsce pracy.

7. Nieodpłatne świadczenia pracownicze są coraz powszechniejszym zjawiskiem w ramach stosunku pracy. Stanowią bowiem niejednokrotnie istotny niepieniężny system motywacyjny. Mimo kilku uchwał Naczelnego Sądu Administracyjnego oraz wyroku Trybunału Konstytucyjnego zagadnienie opodatkowania podatkiem dochodowym nieodpłatnych świadczeń nadal budzi istotne wątpliwości. Analiza powołanego orzecznictwa wskazuje, że niejednokrotnie o uznaniu, czy dane świadczenie należy uznać za „inne nieodpłatne świadczenie” w rozumieniu art. 12 ust. 1 u.p.d.o.f., decydują niewielkie różnice w stanach faktycznych sprawy (np. rodzaj wykonywanej pracy czy zakres obowiązków pracownika). Definicji tego pojęcia w ustawie podatkowej nie ma, a wykładnia gramatyczna nie daje jednoznacznej odpowiedzi, które ze świadczeń oferowanych przez pracodawcę pracownikom uznać za podlegające opodatkowaniu na podstawie art. 12 ust. 1 u.p.d.o.f. W takiej sytuacji wydaje się, że słusznym kierunkiem jest postrzeganie wskazanej regulacji przez pryzmat przepisów prawa pracy. Co do zasady bowiem nie można kwestionować potrzeby używania w prawie podatkowym pojęć zaczerpniętych $\mathrm{z}$ innych gałęzi i nadawania im zmodyfikowanego znaczenia. Niemniej jednak, ze względu na liczne niebezpieczeństwa $\mathrm{z}$ tym związane, „sformułować należy dwa postulaty nawiązujące do podstawowych zasad techniki legislacyjnej:

a) normodawca tworząc unormowania prawa podatkowego powinien posługiwać się terminami i zwrotami występującymi na gruncie innych gałęzi w innym niż na gruncie tych gałęzi znaczeniu tylko wówczas, gdy posłużenie się tymi zwrotami i terminami w znaczeniu nadanym im przez

40 Sygn. III UZP 14/15. 
unormowania tych gałęzi nie jest możliwe ze względu na treść wprowadzanych rozwiązań,

b) nowe znaczenie powinno zostać nadane terminom i zwrotom zaczerpniętym $\mathrm{z}$ innych gałęzi wyraźnie, nie powinno ono wynikać jedynie pośrednio z kontekstu, w jakim ich użyto" ${ }^{41}$.

Wskazane w niniejszym artykule wątpliwości co do kwalifikowania konkretnego świadczenia jako nieodpłatnego świadczenia w rozumieniu art. 12 u.p.d.o.f. stanowią przykład takiej wadliwej legislacji. Niewątpliwie bowiem nie nawiązują wprost do regulacji Kodeksu pracy, podczas gdy wieloletnie spory i potrzeba podejmowania kolejnych uchwał (zarówno przez Naczelny Sąd Administracyjny, jak i Sąd Najwyższy) oraz orzeczeń Trybunału Konstytucyjnego pokazują, że z każdym „nowym” świadczeniem pozapłacowym przepisy te nadal budzą kontrowersje. Należałoby więc albo wprost sformułować definicję w ustawie podatkowej, albo powiązać tę instytucję z Kodeksem pracy, w którym uregulowano zarówno składniki wynagrodzenia, jak i obowiązki pracownika oraz pracodawcy.

\section{BibLIOgRAFiA}

Bartosiewicz A., Kubacki R., PIT. Komentarz, Warszawa 2015.

Bielska-Brodziak A., Interpretacja tekstu prawnego na podstawie orzecznictwa podatkowego, Warszawa 2009.

Bosak M., Majka P., Wplyw regulacji podatkowoprawnych na stosunek pracy w świetle funkcji ochronnej prawa pracy, referat wygłoszony podczas XIX Zjazdu Katedr i Zakładów Prawa Pracy i Ubezpieczeń Społecznych zorganizowanego przez Katedrę Prawa Pracy i Prawa Socjalnego na Wydziale Prawa i Administracji Uniwersytetu im. Adama Mickiewicza w Poznaniu, 15-17 maja 2013 r.

Brejdak P., Glosa do wyroku Trybunału Konstytucyjnego $z$ dnia 8 lipca 2014 r., sygn. akt $K$ 7/13, „Roczniki Nauk Prawnych” 2016, t. 26, nr 1.

Brzeziński B., Podstawy wykładni prawa podatkowego, Gdańsk 2008.

Brzeziński B., Prawo podatkowe a prawo cywilne, [w:] Prawo podatkowe. Teoria. Instytucje. Funkcjonowanie, red. B. Brzeziński, Toruń 2009.

Brzeziński B., Wstęp do nauki prawa podatkowego, Toruń 2003.

Brzeziński B., Nykiel W., Zasady ogólne prawa podatkowego, „Przegląd Podatkowy” 2002, $\mathrm{nr} 3$.

Gomułowicz A., Małecki J., Podatki i prawo podatkowe, Warszawa 2002.

Grabarczyk J., Opodatkowanie przychodów z nieodpłatnych świadczeń, Warszawa 2009.

41 W. Nykiel, Autonomia prawa podatkowego (wybrane zagadnienia), [w:] Konstytucja, ustrój, system finansowy państwa. Księga pamiątkowa ku czci prof. Natalii Gajl, Warszawa 1999. 
Karwat P., Obejście prawa podatkowego. Natura zjawiska i sposoby przeciwdziałania mu, Warszawa 2002.

Mariański A., Nowak-Piechota A., Konstytucyjność opodatkowania pozapłacowych świadczeń pracowniczych, „Przegląd Podatkowy” 2014, nr 11.

Mastalski R., Autonomia prawa podatkowego a spójność i zupetność systemu prawa, „Przegląd Podatkowy” 2003, nr 10.

Mastalski R., Stosowanie prawa podatkowego, Warszawa 2008.

Nykiel W., Autonomia prawa podatkowego (wybrane zagadnienia), [w:] Konstytucja, ustrój, system finansowy państwa. Księga pamiątkowa ku czci prof. Natalii Gajl, Warszawa 1999.

Ostrowski K., Prawo finansowe. Zarys ogólny, Warszawa 1970.

Skibińska M., Sokołowska A., Delegowanie pracowników za granicę, Warszawa 2016.

Strzelec D., Pozapłacowe świadczenia na rzecz pracowników - aspekty podatkowe, „Prawo i Podatki” 2010, nr 9.

Strzelec D., Świadczenia na rzecz pracowników. Aspekty podatkowe, Warszawa 2011.

\section{EMPLOYEE REVENUES ARISING FROM ACCOMMODATION ENSURED}

\section{BY EMPLOYER FOR THE DURATION OF POSTING}

\section{AWAY FROM PLACE OF RESIDENCE}

Summary. Free-of-charge employee benefits are becoming an increasingly common phenomenon in employment relationships. In fact, they are often a significant non-cash incentive system. Despite numerous rulings of the Supreme Administrative Court and the judgment of the Constitutional Tribunal, the issue of income taxation of such benefits still raises considerable doubts. There is no definition of this concept included in the Tax Act and its grammatical interpretation does not provide an unambiguous answer as to which of benefits offered to employees by an employer should be considered as taxable pursuant to Article 12 (1) of the Personal Income Tax Act.

The article is aimed at demonstrating, on the example of taxation of employer-financed accommodation of employees posted to work away from their place of residence, that in a situation when the legislator does not create (and does not define) institutions and concepts specific to tax law - concepts and principles developed in other branches of law should be used. Tax law is an element of the legal system and solutions resulting therefrom should be harmonized with standards of other branches. The legal system should be coherent (free from inconsistencies) and complete (free from gaps). Revenues from an employment relationship comprise all benefits that an employee receives from an employer in relation to being in an employment relationship. In this situation, it is therefore practical to interpret tax law in connection with relevant labor law regulations.

Keywords: free-of-charge benefit, employee revenues, accommodation costs, principle of legal system coherence 